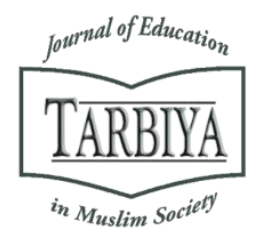

Available online at TARBIYA: Journal of Education in Muslim Society Website:

http://journal.uinjkt.ac.id/index.php/tarbiya

TARBIYA: Journal of Education in Muslim Society, 4(1), 2017, 45-52

\title{
THE INFLUENCE OF E-LEARNING MODEL WEB ENHANCED COURSE TO CONCEPTUAL UNDERSTANDING AND SELF REGULATED LEARNING IN MATHEMATICS FOR ELEMENTARY SCHOOL STUDENTS
}

\author{
Fatkhul Arifin ${ }^{1}$, Tatang Herman ${ }^{2}$ \\ Indonesia Education University of Bandung, Indonesia \\ Email: ikayiep@gmail.com ${ }^{1}$, tatangherman@upi.edu ${ }^{2}$
}

Received: 30 ${ }^{\text {th }}$ April 2017; Revised: $11^{\text {th }}$ May 2017; Accepted: $28^{\text {th }}$ June 2017

\section{Abstract}

This study is aimed to analyze students' conceptual understanding and their self-regulated learning in mathematics between students who are treated using the e-learning model web enhanced course and those who are taught with the power point and to find out the appropriate e-learning design in learning math for elementary school. This study was conducted through quasi-experiment with a pre test-post test control group design. The population of this study is all of the $5^{\text {th }}$ grade students of private Islamic Elementary School (MI) in Jakarta, while the sample is taken from two classes of the population. The instruments used in this study are the essay, questionnaire, and observation sheet. The results showed that 1) students' conceptual understanding of mathematics using e-learning model web enhanced course is better than students who get the learning using power point, 2) students' self-regulated learning treated using e-learning model web enhanced course is better than students' who get the learning using power point, 3) e-learning design that fits in the learning of mathematics in primary schools is e-learning design, incorporating text, images, and animations as well as providing convenience for group discussion. Based on these results it can be concluded that the e-learning webenhanced model affects the conceptual understanding of mathematics and self-regulated learning of elementary school students.

Keyword: conceptual understanding; self-regulated learning; e-learning

\section{Abstrak}

Studi ini bertujuan untuk menganalisa pemahaman konseptual siswa dan pembelajaran mandiri dalam matematika antara siswa yang diperlakukan menggunakan pembelajaran berbasis internet dan siswa yang diajarkan menggunakan power point dan untuk menemukan bentuk pembelajaran berbasis internet yang tepat dalam pembelajaran matematika untuk sekolah dasar. Studi ini diadakan melalui quasi-experiment dengan bentuk pre test dan post test. Populasi studi ini adalah seluruh siswa kelas 5 MI di Jakarta, sedangkan sampel diambil dari dua kelas dari keseluruhan populasi. Instrument yang digunakan dalam studi ini adalah essay, questionnaire, dan lembar observasi. Hasil dari studi ini menunjukkan bahwa 1) pemahaman konseptual siswa dalam matematika dengan menggunakan pembelajaran berbasis internet lebih baik dari pada siswa yang belajar menggunakan power point, 2) pembelajaran mandiri siswa yang menggunakan model pembelajaran berbasis internet lebih baik dari pada siswa yang belajar menggunakan power point, 3) bentuk pembelajaran berbasis internet yang cocok dalam belajar matematika untuk sekolah dasar adalah bentuk pembelajaran berbasis internet, memasukan teks, gambar, dan animasi senyaman mungkin untuk diskusi kelompok. Berdasarkan hasil di atas dapat disimpulkan bahwa model pembelajaran berbasis internet mempengaruhi pemahaman konseptual pelajaran matematika dan pembelajaran mandiri siswa sekolah dasar.

Kata kunci: pemahaman konseptual; belajar mandiri; e-learning

How to Cite : Arifin, F. Herman, T. (2017). The Influence of E-Learning Model Web Enhanced Course to Conceptual Understanding and Self Regulated Learning in Mathematics for Elementary School Students. TARBIYA: Journal of Education in Muslim Society, 4(1), 45-52. doi:10.15408/tjems.v4i1.5536.

Permalink/DOI: http://dx.doi.org/10.15408/tjems.v4i1.5536 


\section{Introduction}

Mathematics is a subject taught from the very beginning of education (elementary school) up to higher education level. This shows that mathematics are important in educational scope and technological development nowadays. Besides, mathematics is one of the subjects that is very critical to the development of students' mathematical ability. National Council of Teachers of Mathematics (NCTM, 2000) formulated the learning objectives of mathematics subject; they are learning to communicate (mathematical communication), to make reasoning (mathematical reasoning), to solve problems (mathematical problem solving), to connect ideas (mathematical connection), and to represent ideas (mathematical representation).

Conceptual understanding is an important part of mathematics learning, because conceptual knowledge is an abstract knowledge about the essence of mathematical principles and the relationship among them (Helmi Khashan, 2014, p. 182). It means that in learning mathematics students should understand the concept of mathematics first to be able to solve questions and to apply the learning to real life situation. According to Kilpatrick, Swafford, and Findell (2001), p. 116) conceptual understanding is an ability to understand conception, operation, and relation in mathematics. Based on the experts' explanation, conceptual understanding enables students to implement and adapt some mathematical ideas with new situation or condition. Also, the indicator of conceptual understanding in this study deal with (1) translation, (2) interpretation, (3) extrapolation (Bloom in Syaiful, 2011, p. 157).

Besides students' mathematics conceptual understanding, self-regulated learning is an important component in mathematics learning that should be developed. Self-regulated learning is defined as a learning activity happening with the self-intention, choice, and responsible of the learners. Self-regulated learning also takes part in determining students' success in learning and make a positive impact on students learning and achievement. Research conducted by Darr and Fisher found that self-regulated learning is strongly in line with students' success in learning (Darr and Fisher, 2005, p. 48). A strong selfregulated learning is expected to improve students' ability whether in individual or group. The lack of students' self-regulated learning is caused by the lack of students' self-confidence on their ability, the lack of motivation to learn, and the lack of conducive learning atmosphere to develop their self-regulated learning. Selfregulated learners are responsible for their learning and vice versa, so self-regulated learning impacts strongly on the success and failure of students' learning achievement.

A reason why students must be selfregulated in learning is that learning sources are accessible everywhere nowadays. Learning is not only bounded at school, but is also happen wherever and whenever. Teachers are no longer the only learning source for students. The students should be active learners to be selfregulated to develop their knowledge. The implementation of technology in the learning process at school has been implemented in Indonesia. Due to the development and advancement of the technology that reached remote areas, with some limitations, today's learning can be conducted through computers that are connected to the internet. This kind of learning is known as web-based learning, internet learning, and is also called as e-learning. E-learning system is an implementation of learning that uses the internet in the form of website or weblog with multimedia content in which it is a process of transforming a conventional learning into digital one. Elearning enables people to set learning objectives 
as they want, so every student is responsible for their learning or learns based on their self awareness (Yucel, 2006, p. 3).Castle and McGuire (2010, p. 36) stated that e-learning enhances learning experience because students can learn wherever and whenever as long as they are connected to the internet without having to attend face to face learning (conventional learning). Then, Purbo (in Rusman, 2012, p. 347) added that e-learning is a term for every technology used to support learning through the internet technology. The Internet, intranet, satellite, tape audio/video, interactive television, and CD-ROM are parts of electronic media used in e-learning. E-learning situation forces the students to be active during the learning. Purbo (in Ngadiyo, 2007, p. 11) mentioned three conditions or requirements to fulfill in designing e-learning; they are: simple, personal, and fast. Based on these theorists, it can be concluded that web-based learning is learning media using the internet that enables learning interaction whenever and wherever in interactive, autonomous, accessible ways and upgradable technology.

Noesgaard and Rikke (2015, pp. 278) revealed that e-Learning effectiveness research has increased in recent years. This is mainly due to the improvement of IT in learning, although e-learning can not be separated from conventional learning. Teachers should be able to combine learning between e-learning with conventional learning, or often we are familiar with hybrid learning. Lynn et al (2014, pp. 121, Bains, 2010, p. 112) defines Hybrid Learning or Blended Learning refers to the combination of elearning based learning methods with face-toface learning methods or conventional methods. The use of this method is still new to educational scope.

Jusoff and Khodabandelou (2009, p. 82) stated that blended learning does not only trim the distance that happens so far to the students and teachers but also it improves interaction between them. In the context of mathematics elearning, Giovannina (2012, p. 317) suggested that the increasing of students' competence is begun from their involvement in learning process until the end of the process, which is suited to the students' needs. Moreover, Haughey (in Zulkifli et.all, 2016, pp. 11-17) mentioned three possibilities of learning system development using e-learning; that is (1) web course: teachers and students are separated and never met each other, (2) web centric course: the using of internet that combines distance learning and face to face learning, (3) web enhanced course: the usage of internet to support learning quality development that happens in a classroom.

Internet functions as an enrichment and communication between students and teachers, and also among the students. Based on Haughey's classification, the e-learning used in this research is web enhanced course model. In this type of e-learning, the intetnet functions as the enrichment and media of communication between teachers and students, among students, or students from other places.

Based on the explanation above, the usage of e-learning beside as its effort to avoid technical problems in learning is a way to solve problems to substantial learning (learning sources). In its process, self-development is available autonomously, cognitively, and affectively. Through e-learning, students are trained to be self-regulated to find out learning sources in certain time in order to increase their knowledge, to make them be active learners, and be more responsible to the learning process for the advancement of their knowledge.

\section{Method}

This research applies quantitative research methodology using quasi-experiment as the 
design. This research is aimed to see the effect of treatment, web enhanced course e-learning model in mathematics learning on the certain variable. The $5^{\text {th }}$ grade of a private Islamic Elementary School (MI) in Jakarta was chosen to be the population of this research, while the samples were taken from two classes of the population. One class, the experimental group, was treated using web enhanced course model while another was taught using conventional teaching method, power point. Then, the sampling technique was done through applying purposive sampling technique. The instruments used to collect the data were the conceptual understanding test, self-regulated learning questionnaire, and observation sheet. The quantitative data were successfully analyzed using Microsoft Excel 2010 program and SPSS 16 for windows. The analysis techniques used are normality testing, homogeneity testing, and analysis co-variance.

\section{Findings and Discussion}

During the pre-test, the average score of students' mathematics conceptual understanding in the experimental group is 31.52 , while in control one is 31.22. The deviation value between these two classes is 0.30 . The experimental group gained $78.8 \%$ or $0.7 \%$ which is higher than the control group that obtained $78.1 \%$ in the pre-test. Both classes have relatively the same ability on conceptual understanding before the treatment was conducted, meaning that the scores both classes gained are still considered low.

This makes a difference in the post-test scores on students' mathematics conceptual understanding. The average value of post-test of mathematics conceptual understanding is 34.97 in the experimental group, while in control one is 32.38 . The difference value is 2.59 , so the experimental class has $87.4 \%$ or $6.5 \%$ higher score than the control class that obtained $81.0 \%$. Based on these data, it can be concluded that students' conceptual understanding of mathematics in the experiment class that was taught using web enhanced course learning model is better than in the control class that was treated using power point.

Besides the conceptual understanding, the result in the pre-test and post-test was also used to know students' self-regulated learning. The average value of students' self-regulated learning on mathematics subject in the experimental class is 87.03 which is higher than the control class that mostly gained 80.21 in the pre-test. The average difference between these two groups is 6.83 which means that both used to have the same attitude in the pre-test.

In the post-test, the value of students' selfregulated learning on mathematics subject in the experimental class is 99.59 that is higher than the control one with average score 89.00. The deviation value shows 10.59 point between these two groups. Based on these data, the result found that self-regulated learning on mathematics subject in the experimental class is better than the control class. Then, the result of hypotheses testing showed that students' conceptual understanding of mathematics treated using e-learning with web enhanced course model is better than the students' in the class treated with a power point that elaborated in the table below:

Table 1. Students' Conceptual Understanding in Mathematics

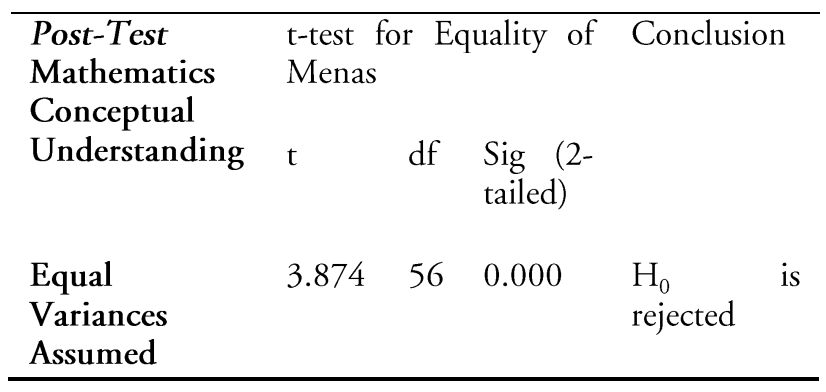


The table above shows the $\mathrm{t}_{\text {count }}=3.874>$ table $=1.673$ with the significance value 0.05 , so the hypothesis states that students' conceptual understanding of mathematics in the experimental class that was treated using elearning with web enhanced course model is better than the control one. Then, the result of hypothesis testing of self-regulated learning in mathematics in the experimental class is also better than the control class that uses power point. The result is described in the table below:

Table 2. Self-regulated Learning in Mathematics

\begin{tabular}{llllllll}
\hline $\begin{array}{l}\text { Post-Tes Sel- } \\
\text { regulated }\end{array}$ & $\begin{array}{l}\text { t-test for } \\
\text { Menas }\end{array}$ & Equality of & Conclusion \\
$\begin{array}{l}\text { Learning in } \\
\text { Mathematics }\end{array}$ & & df & $\begin{array}{l}\text { Sig } \\
\text { tailed) }\end{array}$ & & \\
$\begin{array}{l}\text { Equal } \\
\text { Variances }\end{array}$ & 5.304 & 56 & 0.000 & $\mathrm{H}_{0}$ & is \\
Assumed & & & & & rejected & \\
\hline
\end{tabular}

The table above shows the value of ${ }_{\text {count }}=$ $5.304>\mathrm{t}_{\text {table }}=1.673$ with significance value 0.05 , so the hypothesis is answered that selfregulated learning result in the experimental class is better than the control class. Therefore the alternative hypothesis is accepted.

\section{Students' Conceptual Understanding in Mathematics}

Student centered learning makes better result on students' conceptual understanding. One way to create student centered learning situation is through e-learning. E-learning enables students to get any materials they want, because students can keep going or stop the learning process according to their level of understanding on a concept. Through elearning, students get information that more than the internet can do and it can make the learning practical and efficient because students can ask the teachers online when they found some problems in understanding learning materials in the classroom.
E-learning enables students to be active learners (student centered), and teachers function as facilitators to create fun learning. Teachers deliver materials trough Moodle software and students are required to learn from it, such as answering the questions or solving the problems provided in the program. The tasks given to the students should be accomplished in a limited time. This activity motivates the students to learn the materials, so they will not postpone the learning.

Through e-learning, students' conceptual understanding goes better reflected from their achievement on conceptual understanding in the experimental class is better than the control class. This happened due to in e-learning students can access more information than what the teachers can feed them like in the control class using power point as the learning media. Moreover, elearning enables students to solve problems through reexamining the learning materials in the web pages, group discussion, or having a consultation with the teachers regarding the materials they learn. This interaction does not exist in the conventional class using the power point given by the teachers in face to face. Its learning process is dominated by teacher. This learning limits students' involvement in the learning process because they must follow the learning activities directed by the teachers. This is in line with the research of Umoh and Ekemini (2014, p.68) that found the benefit of e-learning is it can increase students' understanding of mathematics. Students will autonomously dig up information from elearning to expand their learning and knowledge in mathematics from the classroom activities. Also, research conducted by Marzani (2011) found that the increasing of students' conceptual understanding treated using Moodle based elearning goes well then the students attending conventional learning. Like Marzani, Ibrahim and Suardiman (2014) found that there is a 
positive effect of e-learning on students' learning achievement in mathematics subject in Elementary School. Besides, the use of e-learning affects students' learning motivation on mathematics learning in Elementary school.

Generally, it can be concluded that elearning can affect learning in some ways: (1) it gives students chances to use their knowledge and mathematical skill, (2) students actively participate the learning process and express their ideas, (3) it enables students to respond the problems using their own ways, (4) students are motivated to prove and explain the strategies they use to solve problems, (5) e-learning enables students to be experienced in solving problems, so it can increase students conceptual understanding. These results support that students' conceptual understanding can be enhanced through e-learning.

\section{Students' Self-regulated Learning in Mathematics}

E-learning makes students' self-regulated learning becomes more efficient. This can be seen when they need some remedial; students just need to open the materials provided on the web page, so students become more independent in learning. Time efficiency aimed in this case is students does no depend on he teachers when they need some remedial. It avoids timeconsuming so that the time would be more efficient. Mubaraq (2009) stated that web-based learning stimulates students' independence to reconstruct their own knowledge, reflected from the improvement of their conceptual understanding and they give good responses.

E-learning enables students to be more motivated to be self-regulated learners. Bawaneh (2011, p. 43) stated that blended learning could increase students' performance. The role of elearning in creating self-regulated learning due to its learning design that stimulates learning motivation to learn as the basic component in self-regulated learning. The motivation is stimulated because learning through online sources is fun. Motivation is also stimulated because of teachers' guidance and motivation using live discussion (chatting).

The effectiveness of e-learning design in this research on students' self-regulated learning in mathematics can be reflected from students' ability in exploring learning materials from various sources such as to access the materials from internet, whether the web page provided by the teachers which is linked to the address of elearning or using their own ways and solving problems through online group discussion or chatting.

\section{Conclusions}

Based on the data obtained from data analysis and hypothesis testing, it can generally be concluded that e-learning with the web enhanced course model can improve students' conceptual understanding and self-regulated learning in mathematics learning compared with the learning using power point. Especially in some cases, it can be concluded based on the research questions in these points: First, students' conceptual understanding in mathematics treated with e-learning web enhanced course model is better that the students taught using power point. It was showed the significant improvement of the conceptual understanding score in the experimental class rather than in the control class that applies power point. Second, students'selfregulated learning taught using e-learning is better in its process than the class that applies power point for the learning media. It shows that the students' self-regulated learning in the experiment class increases far better than the control class. Third, the appropriate e-learning design for elementary school level is an e- 
learning that provide texts, pictures, animation, and provides access for group discussion with teachers' assistance. Then, it will not only produce fun and attractive learning, but it also facilitates students' interaction in the learning process that in the end will impact student centered learning, students do not depend on teachers.

Based on the finding of this study, some recommendations are addressed: (1) e-learning with web enhanced course model can become an alternative learning methods in elementary school to develop conceptual understanding mathematics, (2) e-learning with web enhanced course model provides attractive learning atmosphere, so students can be more motivated to be self-regulated learners, and (3) a good elearning have a very simple c criteria, attractive layout, and provided with learning activities that equipped with materials, exercises, examples, games in the form of flash media, so the students will not get bored during the learning using elearning media.

\section{References}

A. Seda Yucel. (2006). E-Learning Approach In Teacher Training. Turkish Online Journal of Distance Education-TOJDE July 2006 ISSN 1302-6488 Volume: 7 Number: 4 Article: 11, pp. 1-8.

Bains, M, et.al. (2010). Effectiveness and Acceptability of Face-to-Face Blended and e-learning: a Randomized Trial of Orthodontic Undergraduates. European Journal of Dental Education. ISSN13965883, pp. $110-117$.

Bawaneh, S.S. (2011). The Effects of Blended Learning Approach On Students Performance: Evidence From A Computerized Accounting Course. Interdisciplinary Journal of Research in
Business Vol. 1, Issue. 4, April 2011, pp. 43-50.

Castle, SR. \& McGuire, CJ. (2010). An analysis of student self assessment of online, blended, and face to face learning environments: implication for sustainable education delivery. (Versi elektronik). Journal of International Education Studies., vol 3 no 3, 36 .

Darr, Charles and Jonathan Fisher. (2005). SelfRegulated Learning In Mathematics Classes. [Online]. http://www.nzcer.org.nz/system/files/set20 05_2_044.pdf. [2 April 2017]

Ibrahim, Doni Septumarsa dan Siti Partini Suardiman. (2014). Pengaruh Penggunaan E-Learning Terhadap Motivasi Dan Prestasi Belajar Matematika Siswa Sd Negeri Tahunan Yogyakarta. Jurnal Prima Edukasia, Volume 2, Nomor 1, hlm 6779.

Jeffrey, Lynn M, et.al. (2014). Blended Learning: How Teachers Balance the Blend of Online and Classroom Components. Journal of Information Technology Education: Research Volume 13, pp. $121-140$.

Albano, Giovannina. (2012). "A Knowledge Skill Competencies e-learning Model in Mathematics". Universities and Knowledge Society Journal (RUSC). vol. 9, no 1. p. 306-319.

Jusoff, K. \& Khodabandelou, R. (2009). Preliminery Study On The Role Of Social Presence In Blended Learning Environment In Higher Education. Journal of International Education Studies., vol 2 no 4, 82. 
Khashan, Dr. Khaled Helmi. (2014). Conceptual and Procedural Knowledge of Rational Numbers for Riyadh Elementary School Teachers. Journal of Education and Human Development, 3(4), pp. 181-197.

Kilpatrick, J., Swafford, J., and Findell, B. (2001). Adding it Up: Helping Children Learn Mathematics. Wasington DC: National Academy Press.

M. Zulkifli, et,al. (2016). An Analysis of Information and Communication Technology based Learning Models in School. International Journal of Applied Engineering Research. 11, (23), pp. 11215-11222.

Marzani. (2011). Penerapan E-Learning Berbasis Moodle Untuk Meningkatkan Penguasaan Konsep Dan Keterampilan Berpikir Kritis Siswa Pada Konsep Cahaya Di Smp. (Tesis). Sekolah Pascasarjana, Universitas Pendidikan Indonesia, Bandung.

Mubaraq, L. (2009). Model Pembelajaran Berbasis Web Pada Materi Fluida Dinamis Untuk Meningkatkan Penguasaan Konsep Dan Keterampilan Generic Sains Siswa. Tesis. Bandung: Universitas Pendidikan Indonesia.

National Council of Teachers of Mathematics. (2000). Principles and Standard for School Mathematics. Reston, VA: NCTM.
Ngadiyo. (2007). Pembelajaran E-learning dalam Meningkatkan Mutu Pendidikan. Makalah E-learning/Pelatihan JARDIKNAS 2007.

Noesgaard, Signe Schack and Rikke. (2015). The Effectiveness of E-Learning: An Explorative and Integrative Review of the Definitions, Methodologies and Factors that Promote e-Learning Effectiveness. The Electronic Journal of e-Learning Volume 13 Issue 4 2015, ISSN 14794403 278, pp. 278-290.

Rusman. (2012). Belajar dan Pembelajaran Berbasis Komputer: Mengembangkan Profesionalisme Guru Abad 21. Bandung: CV Alfabeta.

Sagala, Syaiful. (2011). Konsep dan Makna Pembelajaran untuk Membantu Memecahkan Problematika Belajar dan Mengajar. Bandung: Alfabeta.

Umoh, Joseph B and Ekemini T. Akpan. (2014). Challenges of Blended E-Learning Tools in Mathematics: Students' Perspectives University of Uyo. Journal of Education and Learning; Vol. 3, No. 4; 2014. E-ISSN 1927-5269. Published by Canadian Center of Science and Education, pp. 60-70. 